Zeszyty Naukowe Szkoły Głównej Gospodarstwa Wiejskiego

Ekonomika i Organizacja Gospodarki Żywnościowej nr 119, 2017: 195-206

DOI 10.22630/EIOGZ.2017.119.34

Dawid Olewnicki ${ }^{1}$, Paulina Świderska ${ }^{2}$, Magda Marzec ${ }^{1}$, Karolina Nowakowska ${ }^{3}$

${ }^{1}$ Wydział Ogrodnictwa Biotechnologii i Architektury Krajobrazu

${ }^{2}$ Katedra Roślin Warzywnych i Leczniczych

${ }^{3}$ Katedra Roślin Ozdobnych

Szkoła Główna Gospodarstwa Wiejskiego w Warszawie

\title{
Ocena wybranych cech jabłek jako potencjalnych czynników popytowych
}

\section{Wstęp}

Jabłka od dekad należą do najważniejszych owoców, zarówno pod względem produkcji, jak i konsumpcji w naszym kraju. Obecnie Polska zajmuje czwarte miejsce w produkcji tego owocu na świecie i pierwsze miejsce w Europie. Mimo tak dużego potencjału produkcyjnego od lat obserwuje się wyraźny spadek konsumpcji jabłek wśród polskich konsumentów. Chociaż nadal pozostają owocami, które w strukturze konsumpcji owoców mają największy udział, a także dla polskich konsumentów stanowią ważny element diety, to ich znaczenie w obecnej i minionej dekadzie wyraźnie się zmniejszyło.

Jabłka, zaraz po owocach jagodowych, uważane są za bardzo cenne źródło naturalnych związków biologicznie czynnych, w tym polifenoli [Briviba $i$ in. 2007]. Udowodniono także, że konsumpcja owoców i warzyw o wysokiej zawartości polifenoli, czyli jednej z ważniejszych grup związków powstających w roślinie jako metabolity wtórne, niesie dla organizmu ludzkiego istotne korzyści zdrowotne. Związki te biorą udział w unieczynnieniu wolnych rodników w organizmie, w prewencji i leczeniu chronicznych chorób niezakaźnych, tj. chorób naczyniowo-wieńcowych, czy wcześniej wspomnianych nowotworowych [Wojdyło i in. 2010]. Ponadto w jabłkach znajdują się także pektyny zmniejszające stężenie cholesterolu i usuwające $\mathrm{z}$ organizmu toksyczne substancje, np. metale ciężkie. Naturalne węglowodany powoli i bezpiecznie zwiększają stężenie glukozy we krwi, utrzymując je na sta- 
łym poziomie przez dłuższy czas, co także jest bardzo korzystne dla zdrowia [Oszmiański 2009]. Jabłka w swym składzie posiadają około 2-3\% błonnika, w tym połowę stanowi błonnik rozpuszczalny, a zawartość kwasów i cukrów decyduje o atrakcyjności tych owoców dla konsumentów. Co więcej, wiele badań epidemiologicznych związanych z obniżeniem poziomu frakcji LDL cholesterolu wykazuje prozdrowotne właściwości jabłek [Raskin i Ripoll 2004] oraz korzystne działanie w profilaktyce cukrzycy, jak również w chorobach nowotworowych [Barth i in. 2005].

Prócz właściwości prozdrowotnych, czynnikami wpływającymi na wybór jabłek przez klientów mogą być ich cechy zewnętrzne, takie jak np. wygląd, jakość, a także aspekty środowiskowe oraz marketingowe. Wiedza dotycząca wzajemnych relacji między cechami jabłek a preferencjami kupujących jest bardzo ważna z punktu widzenia zaspokajania potrzeb poszczególnych, często znacznie różniących się od siebie grup konsumentów. Może ona wpływać na zwiększenie spożycia tych biologicznie cennych owoców oraz jest istotna dla producentów, gdyż znajomość ich gustu w kwestii odmian, smaku, wyglądu wpływa na wyznaczanie opłacalności danej produkcji oraz wzrost popytu [Czernyszewicz 2008].

Od kilkunastu lat podejmowane są również działania, których celem ma być promocja spożycia owoców i warzyw, podkreślająca ich właściwości prozdrowotne. Jak zaznacza Zambrzycki [2015], o skali działań branży sadowniczej na rynkach zagranicznych może świadczyć budżet trzech kampanii: „Europejskie jabłka dwukolorowe”, ,Jabłka każdego dnia”, „Niezwykłe właściwości zwykłych owoców" wynoszący 12,96 mln euro. Istotna jest zatem ocena wśród konsumentów, czy podkreślanie wybranych walorów jabłek może wpływać na zainteresowanie konsumentów tym produktem.

Celem opracowania była ocena wpływu poszczególnych cech jabłek na ich zakup, a także ocena znajomości wśród konsumentów ich właściwości prozdrowotnych, w tym właściwości antyoksydacyjnych (antyrakowych). $\mathrm{Na}$ tej podstawie podjęto próbę określenia czy zwiększenie tej świadomości może wpłynąć na wzrost popytu na te owoce.

\section{Metodyka}

Wyniki analiz zaprezentowane w niniejszym opracowaniu zostały uzyskane na podstawie badań ankietowych przeprowadzonych wśród 191 konsumentów na rynku warszawskim w latach 2015-2016. Dobór próby był losowy, a same badania przeprowadzane były w trakcie różnych pikników rodzinnych, imprez masowych oraz wśród konsumentów wychodzących ze sklepów spożywczych, w tym wielkopowierzchniowych. Zarówno kwestionariusz ankietowy, jak i ba- 
dania obejmowały zagadnienia dotyczące konsumpcji i nabywania owoców, a także czynników, które determinują te czynności. Wyniki analiz zostały przedstawione za pomocą wskaźników procentowych. Przy ich wyliczeniu za 100\% uznana była wielkość całej grupy badawczej, z kolei w przypadku możliwości udzielenia kilku odpowiedzi przedstawiono łączną sumę wszystkich wskazań. Ankietowanych podzielono również na różne grupy pod względem wybranych cech. Wyodrębniono następujące szeregi rozdzielcze charakteryzujące respondentów, tj. według podziału na kobiety i mężczyzn, respondentów z wykształceniem średnim i wyższym (wykształcenie podstawowe pominięto ze względu na znikomy udział takich osób wśród ankietowanych), a także w wieku do 30 lat, powyżej 30 do 45 oraz powyżej 45 lat. Uwzględniono również podział $\mathrm{z}$ uwagi na posiadane dochody netto na jedną osobę i w tym przypadku wyróżniono respondentów o dochodach do 1000 zł, od 1000 do 1500 zł oraz powyżej 1500 zł, a także zamieszkujących wsie, miasta do 100 tys. mieszkańców, od 100 do 500 tys. oraz powyżej 500 tys. mieszkańców. Niniejszy podział umożliwił ocenę zróżnicowania opinii respondentów w zależności od wybranych czynników. Zbadano w tym przypadku czy istnieją istotne statystycznie różnice między wybranymi czynnikami, m.in. znajomością właściwości prozdrowotnych jabłek i chęcią ich spożywania a czynnikami charakteryzującymi respondentów. W związku z wystąpieniem w kwestionariuszu pytań w skali dychotomicznej oraz w wyniku stwierdzenia braku rozkładu normalnego, w analizach zastosowano nieparametryczny test statystyczny U Manna-Whitneya (w przypadku, analiz dotyczących płci, ze względu na występowanie dwóch zmiennych grupujących) oraz test ANOVA Kruskala-Wallisa (w przypadku gdy w pytaniu występowały 3 zmienne grupujące). W analizach przyjęto poziom istotności $\alpha=0,05$. Jako tło do badań ankietowych przedstawiono ogólne tendencje dotyczące spożycia owoców ogółem (świeżych, schłodzonych mrożonych), w tym jabłek w Polsce w latach 2002-2015. Analizy te odnosiły się do spożycia według danych bilansowych GUS. Za 100\% przyjęto rok 2002, od którego, jak wynika z badań Olewnickiego [2010], zaobserwowano w minionej dekadzie tendencję spadkową spożycia owoców ogółem. W tym przypadku obliczono podstawowe parametry statystyczne dające sumaryczny opis analizowanego zjawiska, m.in. indeksy o podstawie stałej, za pomocą których analizowano zmiany wielkości danych bezwzględnych w ostatnim badanym roku w stosunku do roku podstawowego. Obliczając indeksy łańcuchowe (o podstawie zmiennej), określono średnioroczne tempo badanych zmian, którego miarą $\mathrm{w}$ badanym okresie $\left(\mathrm{t}_{0} ; \mathrm{t}_{1}\right)$ była różnica między średnim indeksem łańcuchowym z tego okresu a jednością [Górczyński 2004]. 


\section{Tendencje w spożyciu owoców w Polsce}

Jak wynika z literatury, od końca lat 90. XX w. przy stale zwiększającej się zamożności społeczeństwa obserwowana jest tendencja spadku spożycia owoców, w tym jabłek [Brzozowski 2008, Olewnicki 2011]. Według Jąder i Wawrzyniaka [2015], w latach 1999-2001 w polskich gospodarstwach domowych konsumowano rocznie średnio 47,0 kg owoców świeżych, a w kolejnych latach wielkość ta ulegała zmniejszaniu.

Biorąc szczegółowo pod uwagę zarówno spożycie owoców ogółem, jak również samych jabłek, w latach 2002-2015 można zaobserwować wyraźny trend spadkowy spożycia tych artykułów (rys. 1). W 2015 roku spożycie owoców ogółem wynosiło 43,08 kg na osobę i było o 11,8\% niższe w stosunku do 2002 roku. Średnie roczne tempo spadku wynosiło w tym czasie $1,0 \%$. Należy podkreślić, iż analizy te opierają się na danych bilansowych (produkcja pomniejszona o eksport i powiększona o import). Jak zauważa Strojewska [2015], spożycie owoców w gospodarstwach domowych w przeliczeniu na osobę według prowadzonych przez GUS badań budżetów gospodarstw domowych jest około $10 \%$ niższe od liczonego według bilansu, ponieważ badania te nie obejmują spożycia w zakładach żywienia zbiorowego, czyli w restauracjach, barach, stołówkach, szpitalach itp.

Znacznie większym tempem spadku w latach 2002-2015 charakteryzowało się spożycie jabłek. W 2015 roku ich spożycie na jedną osobę na rok kształtowało się na poziomie 13,2 kg i było aż o 44,7\% niższe w stosunku do 2002 roku. Średnie roczne tempo spadku wyniosło w tym okresie 4,4\%. Należy podkreślić, że już od początku transformacji ustrojowej w Polsce obserwowano spadek spo-

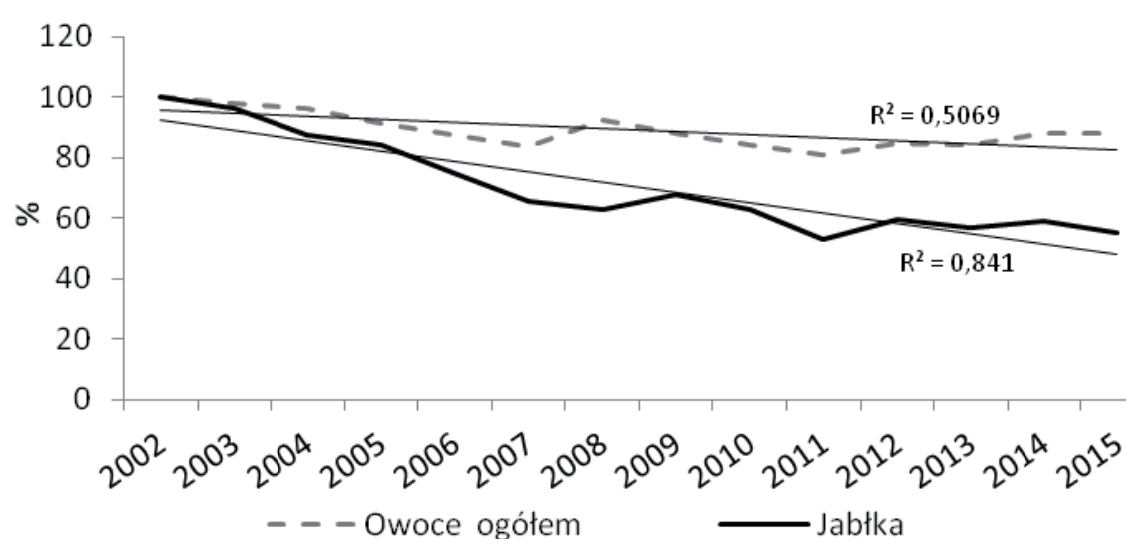

\section{Rysunek 1}

Dynamika zmian spożycia owoców ogółem* oraz jabłek w latach 2002-2015 (na osobę/rok)

* świeże, mrożone i przetworzone

Źródło: Opracowanie własne według danych IERIGŻ-PIB z lat 2003-2016, za GUS. 
życia jabłek. Przykładowo w 1992 roku ich spożycie na jedną osobę w gospodarstwie domowym wynosiło $18,7 \mathrm{~kg}$, a w 2008 roku spadło do $15 \mathrm{~kg}$. Warto w tym miejscu zaznaczyć, iż pod koniec lat 90. wielkość spożycia jabłek przekraczała $22 \mathrm{~kg}$ na osobę [Olewnicki 2011].

Zjawisko spadku spożycia jabłek obserwowano także w innych krajach. W Stanach Zjednoczonych w okresie 100-letnim wraz ze wzrostem zamożności społeczeństwa popyt na jabłka spadał z 30,1 kg w latach 1910-1911 do 8,2 kg (na osobę) w latach 2005-2006 [Brzozowski 2009]. Oznacza to, że jabłka stały się w tym kraju dobrem niższego rzędu. W Polsce w bliższej lub dalszej przyszłości również za takie będą uznawane, choć według Adamczyk [2002], na początku minionej dekady nadal uważane były za dobra wyższego rzędu. Jak podkreśla Makosz [2015], w najbliższych latach konsumpcja jabłek może wzrosnąć pod warunkiem, że nadal będzie skuteczna promocja tego owocu w całym kraju, przede wszystkim przez oferowanie jabłek wysokiej jakości i odmian preferowanych przez konsumentów. Bardzo często w wielu różnych sklepach jakość jabłek zniechęca do ich zakupu. Wygrywają owoce południowe czy jabłka importowane.

\section{Czynniki wpływające na zakup jabłek w opinii konsumentów}

Przeprowadzone analizy wskazują, że wśród respondentów dominowały kobiety, których udział stanowił $64,4 \%$. Biorąc natomiast pod uwagę miejsce zamieszkania, respondenci zamieszkujący tereny wiejskie stanowili ok. 1/3 wszystkich ankietowanych, a respondenci zamieszkujący miasta do 100 tys. mieszkańców 22\%. Miasta od 100 do 500 tys. reprezentowało $11 \%$ ankietowanych, a miasta powyżej 500 tys. $-33,5 \%$. Ponad 3/4 respondentów stanowiły osoby w wieku do 30 . roku życia, $12,6 \%$ osoby w wieku od 30 do 45 lat, a $8,9 \%$ osoby powyżej 45. roku życia.

Wykształcenie średnie deklarowało 48,7\% ankietowanych, a wyższe 48,2\%. Respondenci z wykształceniem podstawowym stanowili jedynie 3,1\%, dlatego ze względu na niewielki ich udział $\mathrm{w}$ dalszych analizach nie uwzględniano tej zmiennej. Biorąc natomiast pod uwagę dochody respondentów, dochód do 1000 zł na jedną osobę $\mathrm{w}$ gospodarstwie domowym deklarowało $27,2 \%$ ankietowanych, dochód od 1000 do 1500 zł-31,9\% respondentów, a powyżej 1500 zł-40,8\%.

Według Czernyszewicz [2008], preferencje konsumentów przy zakupie świeżych jabłek są związane z cechami demograficzno-społecznymii ekonomicznymi. Występuje statystycznie istotna ujemna współzależność między wiekiem nabywców a znaczeniem świeżości, smaku i uszkodzeń owoców, a także dodat- 
ni związek między wykształceniem konsumentów a ważnością cech jabłek, takich jak świeżość, sposób opakowania, kraj pochodzenia i duży wybór owoców. Przy wyborze jabłek konsumenci zwracają uwagę w kolejności na takie cechy, jak: świeżość, uszkodzenia, smak, czystość owoców, odmiana, cena, informacja o braku szkodliwych pozostałości, barwa, kraj pochodzenia, duży wybór, wielkość owoców, technologia produkcji, sposób opakowania, nazwa producenta.

Przeprowadzone badania ankietowe na rynku warszawskim wskazują natomiast, że wśród badanych respondentów wygląd jabłek ma najistotniejsze znaczenie podczas ich zakupu, na co zwróciło uwagę 69,1\% badanych. Również duże znaczenie dla ponad połowy ankietowanych ma smak tych owoców. Warto zwrócić uwagę, że cena jabłek, wśród wskazań respondentów, znalazła się dopiero na czwartym miejscu, co może sugerować, że nie ma ona dużego wpływu na popyt. Osoby, które wskazały, że kupują te owoce, bo je po prostu lubią, stanowiły mniej niż 1/3 ankietowanych. Tylko ok. 1/5 respondentów nabywa jabłka ze względu na ich właściwości odżywcze i prozdrowotne (rys. 2).

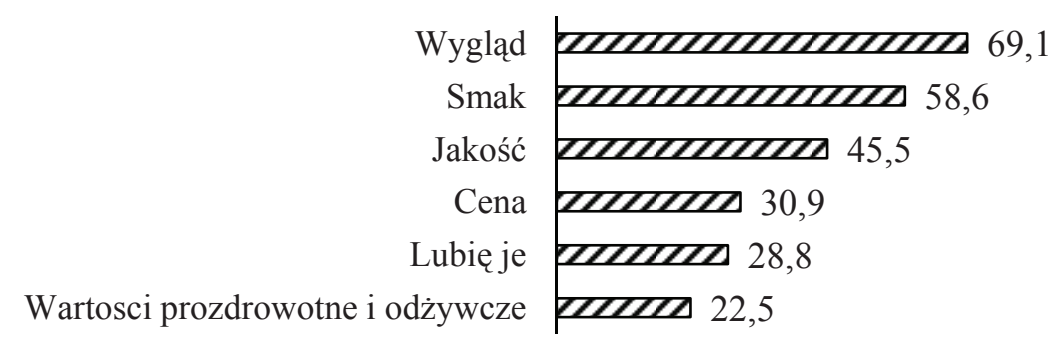

$0 \quad 50 \quad 100$

\section{Rysunek 2}

Czynniki mające wpływ na zakup jabłek przez ankietowanych (suma wskazań respondentów w \%)

Źródło: Opracowanie na podstawie badań własnych.

Poza ogólną oceną czynników, które mają wpływ na zakup jabłek przez respondentów, postanowiono dokonać oceny, czy istnieją statystyczne różnice w ocenie tych czynników w poszczególnych grupach respondentów, uwzględniając płeć, wiek, wykształcenie, miejsce zamieszkania i dochód przypadający na jedną osobę w gospodarstwie domowym. Przeprowadzone analizy wskazały, że w przypadku prawie wszystkich badanych parametrów, nie ma istotnych różnic w podejściu konsumentów do nabywania jabłek. Znaczenie takich cech jabłek, jak cena, wygląd, właściwości prozdrowotne nie jest zróżnicowane w poszczególnych grupach wiekowych, dochodowych oraz np. ze względu na miejsce zamieszkania. Jedynie dwa analizowane parametry istotnie różnią się 
w zależności od wybranych czynników. Biorąc pod uwagę taki czynnik jak smak jabłek, na podstawie przyjętego poziomu istotności $\alpha=0,05$ i statystyki $Z$ testu Manna-Whitneya wynoszącej $Z=4,8955$ oraz wartości $p$-value $=0,001$ można stwierdzić, że występują istotne statystycznie różnice, polegające na tym, iż $\mathrm{w}$ ocenie kobiet smak ma większe znaczenie podczas zakupu niż w przypadku mężczyzn. Również istotne statystycznie różnice występują, biorąc pod uwagę dochody respondentów i ich wpływ na postrzeganie jakości. Na podstawie przyjętego poziomu $\alpha=0,05$ i statystyki $H$ testu ANOVY rang Kruskala-Wallisa wynoszącej $H=10,9181$, przy wartości $p$-value $=0,0122$ (tab. 1), a następnie wielokrotnego porównania średnich rang dla wielu prób można wywnioskować, że dla respondentów posiadających dochody powyżej 1500 zł na osobę jakość owoców ma większe znaczenie niż dla respondentów o dochodach niższych.

Powyższe analizy wskazuja, że tak ważne z punktu widzenia konsumenta właściwości prozdrowotne jabłek w ocenie ankietowanych mają niewielkie znaczenie. Nie odnotowano również istotnych statystycznie różnic biorąc pod

\section{Tabela 1}

Ocena istotności różnic pomiędzy wybranymi parametrami charakteryzującymi respondentów, a czynnikami wpływającymi na zakup jabłek (na podstawie testów U Manna-Whitneya ANOVY Kruskala Wallisa)

\begin{tabular}{|c|c|c|c|c|c|c|c|}
\hline \multicolumn{2}{|c|}{ Wyszczególnienie } & Cena & Wygląd & Smak & Jakość & \begin{tabular}{|l|} 
Właściwości \\
prozdrowotne
\end{tabular} & $\begin{array}{c}\text { Bo je lu- } \\
\text { bię }\end{array}$ \\
\hline \multirow[t]{2}{*}{ Płeć } & $\begin{array}{c}\text { wartość } \\
p\end{array}$ & 0,5171 & 0,3284 & 0,0001 & 0,9948 & 0,5436 & 0,8483 \\
\hline & $Z$ & 0,6490 & 0,9786 & 4,8955 & 0,0063 & 0,6084 & 0,1917 \\
\hline \multirow[t]{2}{*}{ Wiek* $^{*}$} & $\begin{array}{c}\text { wartość } \\
p\end{array}$ & 0,3653 & 0,3687 & 0,6353 & 0,6661 & 0,1829 & 0,1357 \\
\hline & $H$ & 3,1758 & 3,1525 & 1,7073 & 1,5707 & 4,8530 & 5,5500 \\
\hline \multirow{2}{*}{$\begin{array}{l}\text { Wykształ- } \\
\text { cenie }^{\star \star}\end{array}$} & $\begin{array}{c}\text { wartość } \\
p\end{array}$ & 0,5980 & 0,3580 & 4,2838 & 0,6302 & 1,8298 & 0,1052 \\
\hline & $H$ & 1,0526 & 2,0547 & 0,1174 & 0,7297 & 0,3986 & 0,9487 \\
\hline \multirow{2}{*}{$\begin{array}{c}\text { Miejsce } \\
\text { zamiesz- } \\
\text { kania*** }^{*}\end{array}$} & $\begin{array}{c}\text { wartość } \\
p\end{array}$ & 0,2304 & 0,5684 & 0,7846 & 0,1967 & 0,5655 & 0,6760 \\
\hline & $H$ & 4,3040 & 2,0193 & 1,0689 & 4,6811 & 2,0333 & 1,5274 \\
\hline \multirow[t]{2}{*}{$\underset{* \star * * *}{\text { Dochód }}$} & $\begin{array}{c}\text { wartość } \\
p\end{array}$ & 0,4283 & 0,5604 & 0,4430 & 0,0122 & 0,5317 & 0,2853 \\
\hline & $H$ & 2,7708 & 2,0193 & 2,6838 & 10,9181 & 2,2012 & 3,7876 \\
\hline
\end{tabular}

*Wiek (do 30 lat, od 30 do 45 oraz pow. 45 lat), ${ }^{* * W y k s z t a ł c e n i e ~(s ́ r e d n i e ~ i ~ w y z ̇ s z e), ~}{ }^{* * *}$ Miejsce zamieszkania (wieś, miasto do 100 tys. mieszkańców, od 100 do 500 tys. oraz powyżej 500 tys. mieszkańców), ${ }^{* * * \star D o c h o ́ d ~(d o ~} 1000$ zł, od 1000 do 1500 zł, pow. 1500 zł na osobę). Źródło: Opracowanie na podstawie badań własnych. 
uwagę np. wykształcenie respondentów (średnie lub wyższe) lub ich dochodów w postrzeganiu tych wartości. Sugeruje to, że zarówno dla konsumentów ze średnim wykształceniem, jak i wyższym ta cecha owoców ma podobne znaczenie, podobnie jak w przypadku respondentów o niższych lub wyższych dochodach. Przeprowadzone analizy wskazują natomiast, że ponad połowa respondentów zna właściwości prozdrowotne jabłek (53,9\%), a 60,7\% ankietowanych ma świadomość, że jabłka posiadają właściwości antyoksydacyjne (antyrakowe) - tabela 2. Na uwagę zasługuje natomiast fakt, że $83,2 \%$ ankietowanych uważa, że wzrost świadomości konsumentów dotyczącej antyoksydacyjnych właściwości jabłek może spowodować zwiększenie ich spożycia. Inaczej natomiast wygląda sytuacja, kiedy podobne pytanie dotyczyło samych respondentów. Mniej niż połowa $\mathrm{z}$ nich $(45,5 \%)$ nabywa jabłka ze względu na te właściwości, a ponad $1 / 4$ nie ma w tej kwestii żadnego zdania.

Tabela 2

Ocena właściwości antyoksydacyjnych jabłek i ich wpływ na możliwość zwiększenia zakupów tych owoców (w \% wskazań respondentów)

\begin{tabular}{|l|c|c|c|}
\hline \multicolumn{1}{|c|}{ Wyszczególnienie } & Tak & Nie & Nie mam zdania \\
\hline Czy zna Pan/Pani właściwości prozdrowotne jabłek? & 56,1 & 43,9 & - \\
\hline $\begin{array}{l}\text { Czy Pana/Pani zdaniem jabłka mają właściwości } \\
\text { antyoksydacyjne? }\end{array}$ & 60,7 & 39,3 & - \\
\hline $\begin{array}{l}\text { Czy wzrost świadomości konsumentów dotyczącej } \\
\text { antyoksydacyjnych właściwości jabłek może } \\
\text { spowodować zwiększenie ich spożycia? }\end{array}$ & 83,2 & 5,2 & 11,5 \\
\hline $\begin{array}{l}\text { Czy znajomość właściwości antyoksydacyjnych wpływa } \\
\text { na zwiększenie przez Pania/Pana zakupu jabłek? }\end{array}$ & 45,5 & 28,8 & 25,7 \\
\hline
\end{tabular}

Źródło: Opracowanie na podstawie badań własnych.

Również i w tym przypadku dokonano oceny, czy biorąc pod uwagę różne parametry charakteryzujące respondentów, można zaobserwować istotne statystycznie różnice $\mathrm{w}$ znajomości wartości prozdrowotnych jabłek. Jak wynika $\mathrm{z}$ analiz, nie stwierdzono istotnych statystycznie różnic między znajomością tych właściwości, a np. wykształceniem, płcią czy wiekiem respondentów (tab. 3). Zatem niezależnie np. od płci, wykształcenia czy wieku respondenci mają podobny stan wiedzy na temat właściwości prozdrowotnych jabłek.

Powyższe wyniki badań potwierdzają obserwacje rynkowe. Jak zaznacza Zembrzycki [2015], mnogość atutów owoców i warzyw, w szczególności tych związanych z efektami zdrowotnymi daje duży potencjał rozwijania bieżącej mody na zwiększoną konsumpcję tych artykułów spożywczych. Istnienie w świadomości podstawowej wiedzy o pozytywnych skutkach spożycia owoców i warzyw powoduje, że kolejne kampanie promocyjne, zgodnie z efektem 
Tabela 3

Ocena istotności różnic między wybranymi parametrami charakteryzującymi respondentów a znajomościa właściwości prozdrowotnych i odżywczych jabłek (na podstawie testów U Manna-Whitneya i ANOVY Kruskala Wallisa)

\begin{tabular}{|l|c|c|}
\hline \multicolumn{3}{|c|}{ Wyszczególnienie } \\
\hline \multirow{2}{*}{ Płeć } & wartość $p$ & 0,5638 \\
\cline { 2 - 3 } & $Z$ & 0,5770 \\
\hline \multirow{2}{*}{ Wiek } & wartość $p$ & 0,7047 \\
\cline { 2 - 3 } & $H$ & 1,4034 \\
\hline \multirow{2}{*}{ Wykształcenie } & wartość $p$ & 0,8896 \\
\hline \multirow{2}{*}{ Miejsce zamieszkania } & $H$ & 0,2339 \\
\cline { 2 - 3 } & wartość $p$ & 0,7301 \\
\hline \multirow{2}{*}{ Dochód } & $H$ & 1,2960 \\
\cline { 2 - 3 } & wartość $p$ & 0,7256 \\
\hline
\end{tabular}

Źródło: Opracowanie na podstawie badań własnych.

kuli śnieżnej, korzystają z tej wiedzy, jednocześnie ją pomnażając. Nikogo nie zaskakuje dziś powszechnie znane hasło: „Jedz przynajmniej 5 porcji owoców i warzyw dziennie", a wyniki różnych badań wskazują, że na poziomie deklaratywnym konsumenci się z nim zgadzają. Niestety nie przekłada się to tak znacząco na poziom zakupowy. Aby tak się stało, potrzebne jest przeistoczenie mody $\mathrm{w}$ trwałe nawyki żywieniowe. W tym celu konieczne jest pogłębienie edukacji żywieniowej wśród młodzieży i dzieci. Nie mniej ważna jest edukacja tych, którzy młodzież wychowują: rodziców i nauczycieli.

\section{Podsumowanie i wnioski}

Jabłka, ze względu na swoje właściwości prozdrowotne, w tym antyoksydacyjne, powinny należeć do produktów spożywanych regularnie i w dużych ilościach. Niestety w Polsce spożycie owoców od kilkunastu lat wykazuje tendencję spadkową. Mimo opisywanego w literaturze wzrostu zamożności społeczeństwa zarówno po transformacji ustrojowej i w latach minionej dekady, w okresie 2002-2015, średnioroczne tempo spadku spożycia owoców wynosiło $1 \%$. Jeszcze większe tempo spadku spożycia w tym samym czasie zaobserwowano w przypadku jabłek - wynosiło ono aż 4,4\% na rok. Te niekorzystne trendy powodują potrzebę kompleksowych rozwiązań związanych z promocją spożycia owoców, a szczególnie jabłek, zaś sama promocja często opiera się także na podkreślaniu ich wartości prozdrowotnych. Przeprowadzone badania sugerują nato- 
miast, że dla większości respondentów wartości prozdrowotne mają najmniejsze znaczenie podczas zakupu jabłek, a tylko ok $1 / 5$ ankietowanych ma na uwadze tę cechę podczas zakupów. Z kolei największe znaczenie podczas zakupów tych produktów, bo aż dla 3/4 ankietowanych ma wygląd jabłek. Należy podkreślić, że nie zaobserwowano istotnie statystycznego zróżnicowania w poszczególnych grupach respondentów pod względem wieku, płci, wykształcenia, miejsca zamieszkania i dochodów a zwracaniem uwagi na ogólne wartości prozdrowotne jabłek. Nawet jeśli przyjąć, że część konsumentów z założenia kupuje jabłka ze względu na wartości prozdrowotne, to nadal ta cecha jabłek nie jest dla nich najistotniejsza. Powyższe wyniki wskazuja, że promocja spożycia jabłek w oparciu o ich właściwości prozdrowotne i odżywcze może mieć niewielki wpływ na zmianę postrzegania tego produktu przez konsumentów, a w efekcie tego wzrost popytu. Być może szansą na wzrost zainteresowania tym produktem jest ich promocja wykorzystująca podkreślanie ich właściwości antyoksydacyjnych. Wymaga to jednak dalszych badań i analiz przekraczających ramy niniejszego opracowania.

\section{Literatura}

ADAMCZYK G., 2002: Analiza dochodowych uwarunkowań konsumpcji w gospodarstwach domowych w latach 90. Roczniki Akademii Rolniczej w Poznaniu 343, 3-16.

BARTH S.W, FAHNDRICH C., BUB A., DIETRICH H., WATZL B., WILL F., BRIVIBA K., RECHKEMMER G., 2005: Cloudy apple juices decreases DNA damage, hyperproliferation and aberrant krypt foci development in the distal colon of DMH-initiated rats. Carcinogenesis 26, 1414-1421.

BRIVIBA K., STRACKE B., RUFER C.E., WALTZ B., WEIBEL F.P., BUB A., 2007: Effect of consumption of organically and conventionally produced Apple onnantioxidant activity and DNA damage in humans. Journal Agricultural Food Chemistry 55, 7716-7721.

BRZOZOWSKI P., 2008: Zmiany $w$ ekonomice produkcji jabłek $w$ Polsce $w$ latach 1959-2005. Praca doktorska, Instytut Sadownictwa i Kwiaciarstwa, Skierniewice.

BRZOZOWSKI P., 2009: Zagospodarowanie jabłek w Polsce w ostatnim 40-leciu, Zeszyty Naukowe Instytut Sadownictwa i Kwiaciarstwa 17, 41-52.

CZERNYSZEWICZ E., 2008: Ważność wybranych cech jakościowych jabłek dla konsumentów. Żywność. Nauka. Technologia. Jakość, 1(56), 114-125.

GÓRCZYŃSKI J., 2004: Podstawy ekonometrii, Wydawnictwo Wyższej Szkoły Zarządzania i Marketingu, Sochaczew.

IERiGŻ-PIB - Analizy rynkowe: Rynek owoców i warzyw z lat 2003-2016, Wydawnictwo IERiGŻ. 
JAZDER K., WAWRZYNIAK J., 2015: Zmiany w spożyciu owoców $i$ warzyw oraz ich przetworów w Polsce w latach 1999-2013, a zjawisko zrównoważonej konsumpcji, Journal of Agribusiness and Rural Development 3 (37), 427-435.

MAKOSZ E., 2015: Przyszłość polskich jabłek, Biuletyn informacyjny - Rynek owoców i warzyw 3, 10-15.

OLEWNICKI D., 2010: Spożycie krajowych gatunków owoców wobec konkurencji ze strony importu owoców poludniowych, Roczniki Naukowe Stowarzyszenia Ekonomistów Rolnictwa i Agrobiznesu 12 (4), 235-239.

OSZMIAŃSKI J., 2009: Nowe trendy w produkcji soków i nektarów jabłkowych. Przemysł Fermentacyjno Owocowo-Warzywny 4, 12-15.

RASKIN I., RIPOLL C., 2004: Can an apple a day keep the doctor away? Current Pharmaceutical Design 3, 1381-1392.

STROJEWSKA I., 2015: Spożycie owoców, warzyw i ich przetworów w Polsce, Biuletyn Informacyjny - Rynek owoców i warzyw 3, Wydawnictwo IERiGŻ, 2-9.

WOJDYŁO A., OSZMIAŃSKI J., BIELICKI P., 2010: Zawartość wybranych wyróżników chemicznych $w$ owocach trzech odmian jabłoni $z$ uprawy ekologicznej $i$ konwencjonal$n e j$, Journal of Research and Applications in Agricultural Engineering 55 (4), 173-177.

ZEMBRZYCKI P., 2015: Owocna promocja, Biuletyn Informacyjny Agencji Rynku Rolnego $3,30-34$.

\section{Abstrakt}

Celem opracowania była ocena wpływu poszczególnych cech jabłek na ich zakup, a także ocena znajomości wśród konsumentów ich właściwości prozdrowotnych, w tym właściwości antyoksydacyjnych (antyrakowych).Na tej podstawie podjęto próbę określenia, czy zwiększenie tej świadomości może wpłynąć na wzrost popytu na te owoce. Jabłka, ze względu na swoje właściwości prozdrowotne, w tym antyoksydacyjne, powinny należeć do produktów spożywanych regularnie i w dużych ilościach. Niestety w Polsce spożycie owoców od kilkunastu lat wykazuje tendencję spadkową. Ponadto przeprowadzone badania sugerują, że dla większości respondentów wartości prozdrowotne mają najmniejsze znaczenie podczas zakupu jabłek, a tylko ok. 1/5 ankietowanych ma na uwadze tę cechę. Największe znaczenie podczas zakupów tych produktów, bo aż dla 3/4 ankietowanych ma wygląd jabłek. Nawet jeśli przyjąć, że część konsumentów z założenia kupuje jabłka ze względu na wartości prozdrowotne, to nadal ta cecha jabłek nie jest dla nich najistotniejsza.

Słowa kluczowe: owoce, jabłka, spożycie, właściwości prozdrowotne 


\title{
Evaluation of selected characteristics of apples as potential demand factors
}

\begin{abstract}
The aim of the study was to evaluate an impact of selected characteristics of apples as potential demand factors. It seemed interesting to find if an increasing this awareness could increase demand for these fruits. Apples, because of their pro-health properties and especially the antoxidant action, should be consumed regularly and in high amounts. Unfortunately, for the last years a downward trend in fruit consumption in Poland has been observed. The survey made on consumers' preferences shows that the pro-health properties have the smallest impact on purchase of apples for most of consumers and only $20 \%$ buyers take this property into account. For $75 \%$ respondents the most important feature affecting a scale of apple purchase is fruit appearance. Therefore, even if some consumers buy apples because of their pro-health properties this feature is not the most important for their decision.
\end{abstract}

Key words: fruits, apples, consumption, pro-health properties 


\section{Informacje dla autorów artykułów zamieszczanych w Zeszytach Naukowych SGGW, Ekonomika i Organizacja Gospodarki Żywnościowej}

1. W Zeszytach Naukowych SGGW, Ekonomika i Organizacja Gospodarki Żywnościowej publikowane są oryginalne prace naukowe, zgodne z profilem czasopisma.

2. Autor przesyła do redakcji przygotowany według wymogów redakcyjnych tekst artykułu w wersji elektronicznej (na adres: zeszyty_eiogz@sggw.pl) oraz wersję wydrukowaną w 2 egzemplarzach (na adres korespondencyjny redakcji).

3. Do oceny zgłoszonego opracowania Komitet Redakcyjny powołuje dwóch recenzentów spośród osób posiadających co najmniej stopień doktora habilitowanego zatrudnionych głównie poza SGGW.

4. W przypadku tekstu w języku obcym co najmniej jeden $\mathrm{z}$ recenzentów jest afiliowany w instytucji zagranicznej.

5. Recenzenci nie są znani autorom opracowania oraz drugiemu recenzentowi.

6. W szczególnych przypadkach recenzent podpisuje oświadczenie o niewystępowaniu konfliktu interesów pomiędzy nim a autorem recenzowanego opracowania (pokrewieństwo, związki prawne, konflikty, podległość zawodowa i in.)

7. Recenzja ma postać pisemną i kończy się jednoznacznym wnioskiem o możliwość dopuszczenia bądź niedopuszczenia do publikacji zgłoszonego artykułu (formularz recenzji do pobrania na stronie internetowej).

8. W celu zapobiegania przypadkom ,ghostwriting” oraz ,guest authorship" autorzy proszeni są o wypełnienie oświadczenia (do pobrania na stronie internetowej).

9. Po otrzymaniu pozytywnych recenzji, Autor przesyła do redakcji odpowiedź na recenzje i poprawiony po uwagach recenzenta egzemplarz artykułu wydrukowany oraz wersję elektroniczną na adres mailowy redakcji.

10. Lista recenzentów opracowań zgłoszonych do Zeszytów Naukowych jest publikowana minimum raz do roku w ostatnim numerze $\mathrm{z}$ danego roku.

11. Pierwotną wersją wydawanego czasopisma naukowego jest wersja papierowa. Elektroniczna wersja jest zamieszczona na stronie internetowej czasopisma.

12. Autorzy artykułów uczestniczą w kosztach przygotowania do druku (informacja na stronie internetowej czasopisma).

Adres do korespondencji:

Redakcja Zeszytów Naukowych SGGW, Ekonomika i Organizacja Gospodarki Żywnościowej

Szkoła Główna Gospodarstwa Wiejskiego w Warszawie

Wydział Nauk Ekonomicznych

Katedra Ekonomii i Polityki Gospodarczej

ul. Nowoursynowska 166

02-787 Warszawa

tel.: +48225934034

tel.: +48225934037

e-mail: zeszyty_eiogz@sggw.pl

Adres strony internetowej: http://www.wne.sggw.pl/czasopisma/ekonomika-i-organizacjagospodarki-zywnosciowej-zeszyty-naukowe-sggw-w-warszawie/ 
